\title{
EXPLORING PROSPECTIVE STUDENT TEACHER'S QUESTION ON MATHEMATICS TEACHING PRACTICE
}

\author{
Moh Zayyadi $^{1}$ (D) Toto Nusantara $^{2 *}$ (D) Erry Hidayanto ${ }^{2}$ (D), \\ I Made Sulandra' ${ }^{2}$, Abdur Rahman As'ari' ${ }^{2}$ iD \\ ${ }^{1}$ State University of Malang, University of Madura (Indonesia) \\ ${ }^{2}$ State University of Malang (Indonesia) \\ mob.zayyadi1703119@students.um.ac.id, ${ }^{*}$ Corresponding author:totonusantara.fmipa@um.ac.id, \\ erry.bidayanto.fmipa@um.ac.id, \\ made.sulandra.fmipa@um.ac.id, abdur.rahman.fmipa@um.ac.id
}

\author{
Received May 2018 \\ Accepted February 2019
}

\section{Abstract}

This research aims to see and describe the types of questions posed by prospective teachers in learning concepts, principles, procedures and mathematical facts. The mathematics learning is an activity undertaken by teachers, students and learning environments in learning the mathematical material. The mathematics learning, in this case, is the learning of concept, principal, procedures, and factual mathematics. This research is qualitative research, and the subject is $7^{\text {th }}$ semester students of mathematics at Madura University who was doing their field experience practice. The average number of students in each class is 35-40 students and the average age is 17 years. The school where the students of prospective teacher should teach is class IX high school level in Pamekasan and Sampang Regency. The data was collected from video recording an interview, then the data was analyzed, and triangulation was done. Triangulation result would be used as initial conclusion before the final one is taken. The result of this study is, brainstorm questions emphasized more to the concept understanding, procedures, mathematics principals. Divergent questions are questions which stressing more to the concept of understanding, procedures, and mathematics principle and factual. Convergent questions, brainstorm questions are questions which emphasizing on the understanding of mathematics factual. This focal question is more about justifying or giving students choices in answering questions. This type of question to inquire about procedures and mathematical facts to choose the right one.

Keywords - Questions, Prospective students teacher, Mathematics subject.

\section{To cite this article:}

Zayyadi, M., Nusantara, T., Hidayanto, E., Sulandra, I.M., \& As'ari, A.R. (2019). Exploring prospective student teacher's question on mathematics teaching practice. Journal of Technology and Science Education, 9(2), 228-237. https://doi.org/10.3926/jotse.465

\section{Introduction}

Learning is a process to gain knowledge from previous knowledge to form new knowledge (Anthony, 1996). Learning is a behavioral change in the practice of certain experiences, and sometimes it lasts long 
(Schunk, 2012). Classroom learning is an activity undertaken by teachers, students in the learning environment. Teachers must have good communication skills to easily deliver learning materials to students. Teachers should also consider students' responses during the learning process and try to understand the contribution given by students and respond to steps that have been done by students in learning (Nicol, 1998). However, communication in the classroom is still largely dominated by teachers (Viseu \& Oliveira, 2012). A TIMSS video study report (Ragatz, 2010) on teaching practice and student achievement show the number of words spoken by teachers on average of 2,633 words in each lesson and the words spoken by students is generally only 194 words. This indicates a lack of communication between teachers and students and the lack of involvement and student participation in learning.

Asking questions is one way of communicating (Hawkins \& Power, 1996). The kind of knowledge that students construct and communicate during the learning process of mathematics can be done and asked by teachers through questions (Moyer \& Milewicz, 2002). Teacher questions can improve student learning and self-assessment of teacher effectiveness lessons, if not properly packaged can have a negative impact on student learning (McCarthy, Sithole, McCarthy, Cho \& Gyan, 2016). Effective teacher questions in mathematical conversations depend on verbal communication as the primary means of obtaining information from students. Therefore, teachers should not only know the questioning strategy that will be used in learning but must be able to use and apply questions in learning (Gall, 1970). Also, questions raised by students are used to help connect with the prior knowledge that students already possessed (Johar, Patahuddin \& Widjaja, 2017).

The categories of types of teacher questions in learning have been categorized in previous studies. There are many types of questions that teachers can use to ask their students (McCarthy et al., 2016; Heinze \& Erhard, 2006; Dickson \& Hargie, 2006). There are four categories of questions: (1) Probing and follow up, (2) Leading question, (3) Check listing, (4) student-specific questioning, (McCarthy et al., 2016). Reproductive, closed, open, evaluative, and rhetorical questions are a type of research question (Heinze \& Erhard, 2006). In fact, these types of questions may include open questions, closed questions, key questions, process questions and rhetorical questions (Dickson \& Hargie, 2006). This research is more emphasized on questions posed by the students of prospective teachers in learning mathematical objects; concepts, principles, procedures and mathematical facts.

This research will describe the questions posed by prospective teachers when they follow the teacher training program on their students about the material being taught. In this case, the question is a question that encourages students to understand mathematical objects in concepts, principles, procedures and mathematical facts. Therefore, this study aims to see and describe the types of questions posed by prospective teachers in learning concepts, principles, procedures and mathematical facts.

\subsection{Mathematics Learning}

Learning is an active, constructive and contextual process, with new knowledge gained by prior knowledge, meaningful information only when presented in some kind of framework (Davis, 2003). In learning activities, teachers should have the ability and communication skills so that students can receive learning materials properly. Two things as a prerequisite for professionally mastering every type of basic teaching skills (Sukirman, 2012) are: 1) mastering the basics of theory / concept, rules, laws or characteristics of each type of basic teaching skills; 2) conducting a planned and systematic exercise process, starting from the exercises in the form of simulation (microteaching), guided training and selftraining. Teaching skills that teachers should possess include: questioning skills, explaining materials, asking questions, assigning tasks, providing feedback, assessing student learning progress, and when providing scaffolding.

Mathematics learning is an activity undertaken by teachers, students and learning environments in learning the mathematical material. Mathematics teachers are advised to design authentic and interdisciplinary student-centered learning activities to meet 21st-century skills (Umisuzimah, Mahanin, Shahrill, Integrating, Umisuzimah, Mahanin et al., 2017). However, Communication in the classroom is generally 
dominated by teachers (Viseu \& Oliveira, 2012). Therefore, the communication ability of a teacher is an important instrument in the implementation of learning. Also, the cognitive and metacognitive skills of teachers will assist in guiding students to foster deeper and more meaningful mathematical knowledge (Applebaum, Freiman \& Leikin, 2011).

\subsection{Question}

A teacher's question strategy is very important in the learning process because the question is the most commonly used instructional tool (Carpenter, Fennema, Franke, Levi \& Empson, 2000). Through analysis of questions posed by teachers and students' responses made it possible to recognize effective and ineffective question and answer strategies in mathematics class discourse (McCarthy et al., 2016). Furthermore, teachers should need a teaching plan to provide questions that match the number of students, teaching objectives, needs/situations in the learning and teaching style of teachers (Aizikovitsh-Udi \& Star, 2011). There are many types of questions that teachers can use in the process of asking questions to students (McCarthy et al., 2016; Heinze \& Erhard, 2006; Moyer \& Milewicz, 2002; Dickson \& Hargie, 2006).

Question classification is divided into 4 categories: (1) Probing, and follow-up, this type of question is used to further investigate the answers given by the students; (2) Leading question, the main question that directs students' answers through scaffolding; (3) Check listing, teachers ask questions from one question to the next with little regard for student responses; and (4) student-specific questioning, specific questions given by the teacher about something (McCarthy et al., 2016). Reproductive, closed, open, evaluative, and rhetorical questions are a type of question of research (Heinze \& Erhard, 2006). In addition, there are several strategies that can be used when asking questions: (1) Checklisting, following questions as planned, the teacher gives one question to another with little help for student answers (no follow-up questions); (2) The teacher provides the main question with the aim of directing student answers and stops asking questions to teach concepts without encouraging students to respond; (3) ask questions and provide follow-up, teachers use different types of questions to find out more about student responses and other relevant questions, so that students are finally responsive and open to discussion (Moyer \& Milewicz, 2002). The classification of questions also includes open questions, closed questions, key questions, process questions and rhetorical questions (Dickson \& Hargie, 2006).

Some types of questions used as teaching instruments in learning can be divided into several categories (Tofade, Elsner \& Haines, 2013). These types of questions can be seen in the Table 1.

\begin{tabular}{|l|l|}
\hline Types of questions & Description \\
\hline Convergent & $\begin{array}{l}\text { Closed questions, do not offer many answers; converges on one or more list of answers } \\
\text { (checklist); encouraging to give concise responses }\end{array}$ \\
\hline Divergent & $\begin{array}{l}\text { Open questions, giving many responses; allows for exploration in multiple perspectives; } \\
\text { encourage dialogue }\end{array}$ \\
\hline Focal & Students are required to choose or justify a position. \\
\hline Brainstorm & Questions that generate many ideas or points of view \\
\hline Shotgun & Questions that contain certain content areas. \\
\hline Funnel & Some questions started broadly and gradually led to a more focused inquiry \\
\hline
\end{tabular}

Table 1. Types of questions based on teaching instrument

\subsection{Mathematics Object}

Understanding of mathematical concepts can be identified by asking the following questions: 1) How to describe concepts with their language, 2) How to identify or give examples, and 3) How to use the concept correctly in various situations? (National Council of Teachers of Mathematics, n.d.). Concepts can be reconstructed through the following activities: 1) proposing concept definitions, 2) constructing and evaluating examples rather than examples, 3) definition of nature and relations, 4) construction of 
definitions by explanation or argument, 5) revision of definitions, 6) proving and reasoning about the relationship system, 7) asking the definition of the question, and 8) negotiating the criteria of adequacy and acceptance of the definition, so that the concept can be taught through various learning activities (Kobiela \& Lehrer, 2015).

The tasks assigned to students to facilitate the understanding of concepts should be as follows: 1) non-routine, 2) short, 3) reconstruction based not just memory, 4) contextual, 5) focus on representation and explanation of solutions (NCTM, 2003). Conceptual findings can be compiled using three interrelated skills: 1) identify what is important in a classroom situation, 2) make connections between parts of the situation and principles of education, 3) reasoning situations in context (Van Es \& Sherin, 2002).

Procedures are rules for solving math problems. Studying the procedure aims for students to perform the procedure both in understanding and performing steps in doing a task in an ordered manner. Principles in mathematics are the most complex mathematical basic objects. Facts in mathematics are conventions or agreements that can be presented in a symbolic form, which is generally understood. Principles can contain a set of facts, concepts, and procedures. The form of principle can be the theorem, lemma, among others.

\section{Methodology}

\subsection{Participant}

The subject of this research is 7 th-semester students in mathematics education department of Madura University who are take course of teacher training program (PPL). PPL is a course that must be taken by students of mathematics education department at the 7 th semester. In this research, from 5 student candidates to teach for about 3-4 meetings. The average number of students in each class is 35-40 students and the average age is 17 years. The school where the students of prospective teacher should teach is class IX high school level in Pamekasan and Sampang Regency. One of the materials taught by students is an up and down function using the Think-Pair-Share (TPS) type cooperative learning model. Each student performs teaching which will be recorded in the form of video recording. For this study, the video was analyzed by researchers to observe the interaction of students -students of prospective teachers in the questioning practice of prospective teachers and students' responses.

\subsection{Data Collection}

The data in this study were obtained from video recordings and interviews. Video recording is used to know the interaction in the classroom focus on the questions posed by prospective teachers during the learning process of mathematical objects both concepts, principles, procedures and mathematical facts. Questions posed by prospective teacher students will be in the form of questions and coded patterns and will be classified/categorized based on the pattern that is formed. The type of interview used in this study is a semi-structured interview. Semi-structured interviews are a type of interview for qualitative research in which questions are predetermined but are still in an open format so that researchers have control over the topics for interviews (Ayres, 2008).

\subsection{Data Analysis}

The data analysis of this research is qualitative inductive, an analysis based on the data obtained then developed a certain relationship pattern or become a hypothesis. From the results of the first, second and third observations of each teacher, then researchers do triangulation. In analyzing the data, the researcher reads the transcripts and field notes of each case several times to gain a deeper insight into each case. The triangulation result will be validated which will be concluded based on the result of the student of the teacher candidate. Drawing conclusions from the data that has been collected and analyzed to be the initial conclusion are still temporary and can change if found strong evidence. So in this study after concluding, researchers verify to check back conclusions with the results of research (Miles, Huberman \& Saldana, 2014) 


\section{Result}

Data in this research is qualitative data in the form of questions posed by prospective teachers in the process of learning mathematics during the implementation of PPL progress. Data obtained by recording interaction between the student of teacher candidate with the student in learning mathematics through passive participation method by using handphone recorder. The data were collected three times with three meetings conducted by five prospective teachers during the learning process. Some types of questions are asked by a prospective student teacher in learning mathematics as in the Table 2 .

Based on the Table 2, the tendency of question type used is brainstorm question $(50,2 \%)$ for three times implementation of learning from 5 research subject, so that in every meeting of the student of a teacher candidate ask the question about 8-12 times. Then the type of question diverges or is open (23.7\%). Therefore, in every student meeting, prospective teachers ask questions as much as 2-4 times. In the convergent type of question (15.3\%) analyzed the question asked 2-3 times in each meeting and the type of choice or focal question (10.8\%). The types of questions of the funnel and shotgun have not been seen and are not used in the learning carried out by subject. Therefore, researchers did not identify the types of questions.

\begin{tabular}{|c|c|c|c|c|}
\hline \multirow[b]{2}{*}{ Subject } & \multicolumn{4}{|c|}{ Types of questions } \\
\hline & Brainstorm & Convergen & Divergent & Focal \\
\hline Subject 1 & 29 & 9 & 11 & 7 \\
\hline Subject 2 & 25 & 8 & 12 & 5 \\
\hline Subject 3 & 26 & 8 & 15 & 4 \\
\hline Subject 4 & 25 & 10 & 13 & 8 \\
\hline Subject 5 & 20 & 3 & 8 & 3 \\
\hline Sum & $125(50.2 \%)$ & $38(15.3 \%)$ & $59(23.7 \%)$ & $27(10.8 \%)$ \\
\hline
\end{tabular}

Table 2. Types of questions are asked in learning mathematics

\subsection{Brainstorm Questions}

This type of brainstorm question is more commonly used by research subjects. This type of question is giving many points of view and more to the goal of asking for an understanding of the mathematical principle, as in the following conversation:

Subject: okay, if none of you understand. Look at the picture on the board. Does Picture 1 show the increasing function or decreasing function?

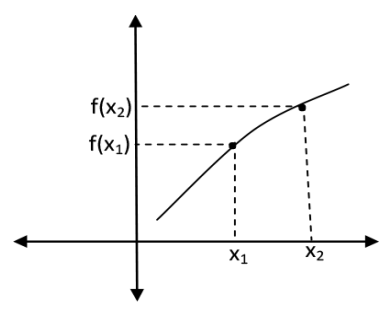

Picture 1

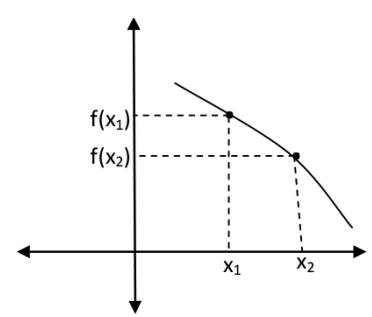

Picture 2

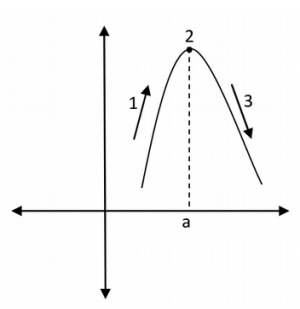

Picture 3

Students: Increasing function

Subject: Why did you call it increasing function?

Students: because the graphic is up

Subject: so, do you mean Picture 2 is increasing function as well? (pointing on Picture 2, right to the left)

Students: because $x_{1}<x_{2}$

Subject: right, so Picture 1 is increasing function because when $x_{1}<x_{2}$ then $f\left(x_{1}\right)<f\left(x_{2}\right)$. So Picture 2 is decreasing function. Why is it so? Students: because $x_{1}<x_{2}$ and $f\left(x_{1}\right)>f\left(x_{2}\right)$ 
From the question posed by the prospective student teacher about the rules to determine that the function is said to function up. This can be known by the question of the student "Why did you call it increasing function?", With the question the teacher wants to know the reason for the students and the rules so that said the function is said to increase function. Also, students provide scaffolding to further convince students in understanding the students' mathematical principles. The student explains that in Figure 1 it is a rising function, because when $x_{1}<x_{2}$ then $\left(x_{1}\right)<f\left(x_{2}\right)$. Next, the student asks a follow-up question by asking "so, do you mean Picture 2 is increasing function as well?". The purpose of this question is to ask the students' understanding of mathematical principles in determining the descending function. By giving the students explanations made before students can answer and understand student questions.

\subsection{Focal Questions}

The subjects of this study also used focal questions in justifying or providing choice answers to students. This type of question aims to provide opportunities for students to participate in responding and evaluating the settlement of a friend or teacher. This type is not very used in teaching mathematical concepts, but this type of question is used in a certain time, more emphasis on mathematical procedures and usually sentence is used is "right or wrong", as in the following conversation:

Subject: so, $x=-3$ atau $x=1$. To find out which point is this function will be increasing function or decreasing function. Let's make the interval solution

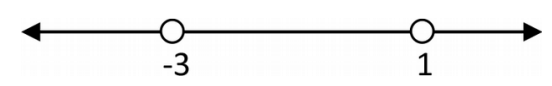

Determining the positive and negative areas, we can examine the point.

\section{Between -3 and 1, which number will we take?}

Student: 0

Subject: Substitute $x=0$ to $f^{\prime}(x)=x^{2}+2 x-3$

$$
f^{\prime}(0)=(0)^{2}+2(0)-3=-3
$$

on the right of 1 , we take number 2

Student: ok

Subject: substitute $x=2$

$$
\begin{aligned}
& f^{\prime}(2)=(2)^{2}+2(2)-3=5 \\
& \text { on the left of }-3 \text { we can take }-4
\end{aligned}
$$

\section{Student: ok}

Subject: substitute $x=-4$

$$
f^{\prime}(-4)=(-4)^{2}+2(4)-3=21
$$

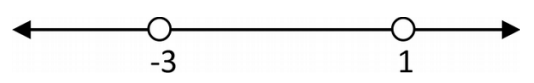

so the area is

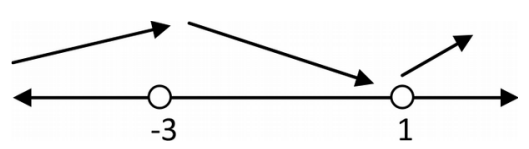

The area of increasing function is $x<-3$ and $x>1$. because $f^{\prime}(x)>0$, so it is a positive area.

Example 2. Focal question

From conversations conducted by students and students in determining positive areas or negative areas, prospective students ask questions between " 3 and 1 we take what number?". with the choice of whether including a positive area or a negative area the student performs the steps substituted $x=0$ to $f^{\prime}(x)=$ and we substitute $\mathrm{x}=2$ and we substitute $\mathrm{x}=-4$. Then the student can determine the rising area. Therefore, the type question asks about the mathematical procedure to choose the correct one. 


\subsection{Divergent and Convergent Questions}

Another type of question that is also used in mathematics learning by prospective math teacher students is the type of divergent (open) and convergent (closed) questions. This type of open questioning in this case provides general questions with the aim of giving students an opportunity to respond to what is being asked. Open questions in learning the concept of mathematics more often occur at the beginning of learning or giving explanations of prospective teachers. Student prospective teachers using open questions tend to know the response of students in the learning process. The response given by the students is used as a tool for prospective teachers to use appropriate strategies used in learning. Meanwhile, closed questions are used by students of prospective teachers in giving questions that only respond with one answer. This type of questioning requires little response from students, and sometimes the responses given by the students are concise. This closed question is sometimes used only to recall the concept / procedure that has been done before. Examples of open and closed questions as in the following conversation:

Subject: right, because when $x_{1}<x_{2}$ then $f\left(x_{1}\right)>f\left(x_{2}\right)$. Do you understand the different between increasing function or decreasing function?

Students: yes, we do

Subject: now look at Picture 3, which number showed the increasing function?

Students: number 1

Subject: north side, which number show the increasing function?

Students number 1

Subject: right, so number which showed the increasing function is number 1 , because when $x_{1}<x_{2}$ then $f\left(x_{1}\right)<f\left(x_{2}\right)$ (pointing on graphic number 1). So, for number 3 is decreasing function. Then what about number 2?

Students: I don't know.

Example 3. Open Question

Questions posed by students with the question "Do you understand the difference between increasing function or decreasing function?" To ask students' abilities in mathematical principles. This is because in understanding the function up and down function students must understand the requirements needed to be said as a function of rising or fall function. Next, the students ask the question "now look at Picture 3, which number showed the increasing function?" To know students can classify which is an example and not an example of the function.

Subject: Right, because in the question of interval increasing function, then $f^{\prime}(x)>0$, so the solving area is the positive area

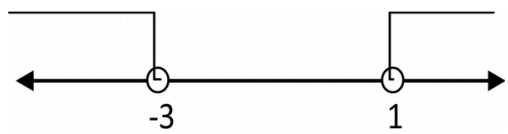

So the interval $x$ to make $f(x)$ increasing is $x<-3$ or $x>1$

Is there any still not understand it?

Students: understand

Subject: now for (b) exercise. Determine the interval x to make $\boldsymbol{f}(\mathbf{x})$ decreasing. So how to make $\boldsymbol{f}(\boldsymbol{x})$ decreasing? Students: $f^{\prime}(x)<0$

Example 4. Closed question

\section{Discussion}

Based on the results of data obtained, the questions used in mathematics learning by prospective teachers, especially in learning concepts, procedures, principles and mathematical facts can be seen in the Table 3 . 


\begin{tabular}{|c|c|c|c|c|}
\hline \multirow{2}{*}{ Kind of questions } & \multicolumn{4}{|c|}{ Mathematics objects } \\
\cline { 2 - 5 } & Concept & Procedures & Principal & Factual \\
\hline Brainstorm & $\square$ & $\square$ & $\square$ & $\square$ \\
\hline Divergent & $\square$ & $\square$ & & $\square$ \\
\hline Convergent & & & & $\square$ \\
\hline Focal & & $\square$ & & $\square$ \\
\hline
\end{tabular}

Table 3. The use of these types of questions in the learning of mathematical objects

Types of brainstorm questions posed by prospective teachers to understand students' understanding of concepts, implement procedures and questions about understanding students' mathematical principles. If the student has not been able to respond to the questions given, the prospective teacher will ask more questions or even give scaffolding to the students. This is based on the researcher's initial interview with the research subject. The submission of such questions emphasizes the goals of the teacher (brainstorm). This brainstorm question is used to understand students' understanding of mathematical concepts and procedures that have been taught. In this brainstorm question, sometimes the student candidate gives some scaffolding to be able to dig deeper into understanding the concepts and procedures obtained. This is in line with what McCarthy et al. (2016) thinks this type of question is used to further investigate the answers given by the students. In his research, these types of questions are called probing and follow up questions. Also, in the Moyer and Milewicz (2002) study of the type of questioning and follow-up, teachers use different types of questions to find out more about student responses and other relevant questions, so that in the end the students respond and able to discuss.

Types of convergent and divergent questions are open-ended questions in learning mathematical concepts, more often used at the beginning of learning or providing explanations by prospective teachers. Student prospective teachers using open-ended questions tend to know the child's understanding of mathematical concepts in general, asking students' abilities in mathematical principles and to know students can classify which is an example rather than an example. Student prospective teachers using open questions tend to know the responses / responses of students in the learning process. The responses provided by the students serve as a tool for using the right strategy used in learning. Closed questions are used by prospective teachers in giving questions that have only one answer. This is by Heinze \& Erhard (2006) research which states open questions will provide more responses from the questions given. This focal question is used by prospective teachers to justify or give students choices in answering questions. The type question asks about the mathematical procedure to choose the correct one.

Based on research results the frequency of brainstorm questions is more widely used than other types of questions. Student prospective teachers use brainstorm questions by providing follow-up questions to find out the extent of understanding the concept that has been taught. This is consistent with teachers found asking questions that require a yes or no response more often than high-level questions that require students to explain or justify student thinking (Kawanaka \& Stigler, 1999).

\section{Conclusion}

The conclusion obtained from this research is the submission of more brainstorming questions by prospective teachers. This brainstorm question is used to understand students' understanding of a concept, a mathematical procedure that has been taught and to assess students' understanding of mathematical principles. In this brainstorm question, sometimes the student candidate gives some scaffolding to be able to give more understanding of the concepts and procedures. Student prospective teachers using open questions tend to know the child's understanding of mathematical concepts in general. Student prospective teachers using open questions tend to know the response of students in the learning process. The response given by the students can help the students of prospective teacher to find appropriate strategies to apply learning. Asking students' abilities in mathematical principles and knowing students can classify which is an example rather than an example. Closed questions used by prospective teachers in giving questions that have only one answer to know about mathematical facts. In this study the 
types of questions that are also asked by prospective teachers in learning are focal questions. This focal question is more about justifying or giving students choices in answering questions. This type of question to inquire about procedures and mathematical facts to choose the right one.

In general, effective questions can be done based on the goals and conditions in the learning that is done. The results and final discussions are a good starting point for rethinking how to introduce effective questioning for future maths teachers in Madura University.

\section{Declaration of Conflicting Interests}

The authors declared no potential conflicts of interest with respect to the research, authorship, and/or publication of this article.

\section{Funding}

The authors received no financial support for this search, authorship, and/or publication of this article.

\section{References}

Aizikovitsh-Udi, E., \& Star, J. (2011). The skill of asking good questions in mathematics teaching. Procedia - Social and Behavioral Sciences, 15, 1354-1358. https://doi.org/10.1016/j.sbspro.2011.03.291

Anthony, G. (1996). Active Learning in a Constructivist Framework. Educational Studies in Mathematics, 31(4), 349-369. https://doi.org/10.1007/BF00369153

Applebaum, M., Freiman, V., \& Leikin, R. (2011). Prospective teachers' conceptions about teaching mathematically talented students: Comparative examples from Canada and Israel. Montana Mathematics Enthusiast, 8(1/2), 255-289. Available at: http://login.ezproxy.lib.umn.edu/login? url=http://search.ebscohost.com/login.aspx?direct=true\&AuthType=ip,uid\&db=aph\&AN=71149410\&site=ehost-live

Ayres, L. (2008). Semi-structured interview. In Given, L.M. (Ed.), The SAGE encyclopedia of qualitative research methods. Thousand Oaks, CA: SAGE Publications, Inc.

https://doi.org/10.4135/9781412963909.n420

Carpenter, T.P., Fennema, E., Franke, M.L., Levi, L., \& Empson, S.B. (2000). A Research-Based Teacher Professional Development Program for Elementary School Mathematics. In National Center for Improving Student Learning and Acbievement in Mathematics and Science. Wisconsin-Madison.

Davis, G.E. (2003). Teaching and classroom experiments dealing with fractions and proportional reasoning. Journal of Mathematical Behavior. https://doi.org/10.1016/S0732-3123(03)00016-6

Dickson, D., \& Hargie, O. (2006). The Handbook of Communication Skills. (3rd ed.). Routledge. https://doi.org/10.1007/978-3-319-20185-6

Gall, M.D. (1970). The Use of Questions in Teaching. Source: Review of Educational Research, 40(5), 707-721. Available at: http://www.jstor.org/stable/1169463 https://doi.org/10.3102/00346543040005707

Hawkins, K., \& Power, C.B. (1996). Gender Differences In Questions Asked During Small Decision-Making Group Discussions. Small Group Research, 30(2), 235-256.

https://doi.org/10.1177/104649649903000205

Heinze, A., \& Erhard, M. (2006). How much time do students have to think about teacher questions? an investigation of the quick succession of teacher questions and student responses in the German mathematics classroom. ZDM - International Journal on Mathematics Education, 38(5), 388-398.

https://doi.org/10.1007/BF02652800 
Johar, R., Patahuddin, S.M., \& Widjaja, W. (2017). Linking pre-service teachers' questioning and students' strategies in solving contextual problems: A case study in Indonesia and the Netherlands. The Mathematics Enthusiast, 14(1-3), 101.

Kawanaka, T., \& Stigler, J.W. (1999). Teachers' Use of Questions in Eighth-Grade Mathematics Classrooms in Germany, Japan, and the United States. Mathematical Tbinking and Learning, 1(4), 255-278. https://doi.org/10.1207/s15327833mt10104_1

Kobiela, M., \& Lehrer, R. (2015). The Codevelopment of Mathematical Concepts and the Practice of Defining. Source: Journal for Research in Mathematics Education, 46(4), 423-454.

https://doi.org/10.5951/jresematheduc.46.4.0423

McCarthy, P., Sithole, A., McCarthy, P., Cho, J., \& Gyan, E. (2016). Teacher questioning strategies in mathematical classroom discourse: A case study of two grade eight teachers in Tennessee, USA. Journal of Education and Practice, 7(21), 80-89.

Miles, M., Huberman, A., \& Saldana, J. (2014). Qualitative Data Analysis, A Methods Sourcebook (3rd ed.). USA: SAGE Publications, Inc.

Moyer, P.S., \& Milewicz, E. (2002). Learning to Question: Categories of Questioning Used by Preservice Teachers During Diagnostic Mathematics Interviews. Journal of Mathematics Teacher Education, 5(4), 293-315. https://doi.org/10.1023/A:1021251912775

Nicol, C. (1998). Learning to Teach Mathematics: Questioning, Listening, and Responding. Educational Studies in Mathematics, 37(1), 45-66. Available at: http://www.jstor.org/stable/3482682 https://doi.org/10.1023/A:1003451423219

Ragatz, A. (2010). Di dalam Ruang Kelas Matematika di Indonesia: Studi Video TIMSS tentang Praktek Mengajar dan Capaian Siswa, 1-4.

Schunk, D. (2012). Learning Theories An Educational Practice (VI). Pearson Education, Inc.

Sukirman, D. (2012). Pembelajaran Micro Teaching. Jakarta, Indonesia: Direktorat Jenderal Pendidikan Islam Kementrian Agama.

Tofade, T., Elsner, J., \& Haines, S.T. (2013). Best practice strategies for effective use of questions as a teaching tool. American Journal of Pharmaceutical Education, 77(7). https://doi.org/10.5688/ajpe777155

Umisuzimah, H., Mahanin, H., Shahrill, M., Integrating, M. A., Umisuzimah, H., Mahanin, H. et al. (2017). Integrating the Use of Interdisciplinary Learning Activity Task in Creating Students' Mathematical Knowledge. International Journal of Research in Education and Science, 3(1), 280-298.

Van Es, E.A., \& Sherin, M.G. (2002). Learning to Notice: Scaffolding New Teachers' Interpretations of Classroom Interactions. Journal of Technology and Teacher Education, 10(4), 571-596.

Viseu, F., \& Oliveira, I.B. (2012). Open-ended tasks in the promotion of classroom communication in Mathematics. International Electronic Journal of Elementary Education, 42(2), 287-300.

Published by OmniaScience (www.omniascience.com)

Journal of Technology and Science Education, 2019 (www.jotse.org)

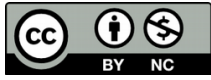

Article's contents are provided on an Attribution-Non Commercial 4.0 Creative commons International License. Readers are allowed to copy, distribute and communicate article's contents, provided the author's and JOTSE journal's names are included. It must not be used for commercial purposes. To see the complete licence contents, please visit https://creativecommons.org/licenses/by-nc/4.0/. 